\title{
Choosing a career in science: The Nigerian student perception
}

Ezeweani, U. Louis

Delta State University, Abraka, Nigeria (louisezeweani@yahoo.com)

Atomatofa, Rachel O.

Delta State College of Physical Education, Mosogar, Nigeria(atomatofa.ro@gmail.com)

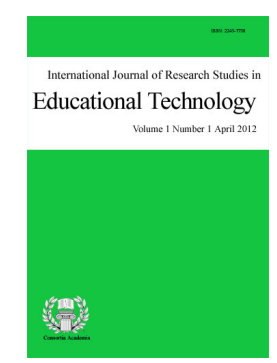

ISSN: 2243-7738 Online ISSN: 2243-7746

\begin{abstract}
The selection of subjects is a vital incident in the life of the senior secondary school child hence the need for proper guidance and encouragement to boost their interest and perception of science subjects. In this research a total of 180 senior secondary III students (91 boys and 89 girls) were carefully selected from four secondary schools in Delta State Nigeria, for the study. One research question and 4 hypotheses guided the study. The instrument used is the Subject Choice and Perception Questionnaire (SCAPQ). It was discovered that $40.6 \%$ of the students studying sciences as a result of personal interest had better perception of sciences than the $32.7 \%, 20.6 \%$ and $6.1 \%$, influenced to study science by parental, teacher and gender factors respectively. Also, there was no significant difference between perception of boys and girls about science subjects. Conclusion and recommendations were made based on the results.
\end{abstract}

Keywords: parents; teachers; gender; personal interest; influence 


\section{Choosing a career in science: The Nigerian student perception}

\section{Introduction}

With advert of the millennium goals, choosing a career for the future is one of the major challenges presently faced by Nigerian secondary school students. It involves decisions on the right subjects to offer that will make their career dreams come true. In Nigeria the choice of subjects are often made at an age when most of the students are far too young and immature to be fully aware of the consequences of some of the choices they may make in terms of their future ambition. According to Ipaye (1991), most students have limited or no reliable information or guide in their choice of subject or careers. They are being influenced by aptitude, talents and several other factors of which home background is not left out. It is necessary that a student take proper care and get adequate help early enough before making decision on subject/career choice that will render later efforts useless.

\section{Background literature}

Issues of career choice have been and will continue to be a vital point in the lives of secondary and university students in Nigeria. This issue has attracted the interest of several researchers and even the government over the past years. Since the 50's many researchers (Donald, 1953; Ginzberg, 1957) have made lots and lots of efforts in contributing to see how students in this category can be helped; in the 70's to 90's researchers like Durojaiye (1973), Adedibu (1986), Akpan (1986), Ipaye (1991), Keeves (1992), and Ovri (1999) also contributed to how science students can be guided to make correct subject choices that are relevant to their future career in Science, Technology, Engineering and Medicine. More recently in 2000 and up till date researchers are still researching on career choice and subject choices and are still finding out the factors affecting or influencing such choices (Gerhard, 2009; Ohiwerei \& Nwosu, 2009; Yara, 2009; Tesfaye, 2010).

Amongst factors which researchers have studied that affect students' choice of subject are personal interest, attitude toward the subject, sex, prestige, peer pressure parental influence and school factors which includes teacher's influence. In spite of the economic recession decisions on career choice have continue to be on the increase and any mistake made can block the realization of one career dream. For instance a student who wants to study medicine but has no interest in chemistry or failed chemistry may not achieve his career goal. It is known that students do not like all the subjects in the curriculum and even if they do they cannot offer all because they need to focus on their areas of Arts, Sciences or Social sciences when they get to senior secondary classes (Ovri, 1999).

Science students have varying perceptions of their sciences. Some are enjoying the subjects irrespective of whom or what influenced their choices while others who are not enjoying sciences have to struggle all the way. Several researchers have come up with various findings on factors affecting students' choice of subjects, especially science subjects. Akpan (1986) conducted a research on 1,240 Nigerian students (aged 12-18 years) from 31 secondary schools. The students were given tests assessing intelligence, attitudes toward science, personality, and subject choice. Results show that attitude toward science was the most important factor in science subject choice, followed by IQ. Sex and personality were important to a lesser degree. A similar research was carried out by Keeves (1992) who carried out a study on science subject choice and discovered that interest of students towards choosing science subject decreases as they progress from one class to the other. He then recommended that science subjects should be well taught early enough to enable students develop love for the subjects. Students can develop positive attitude towards science subjects irrespective of how and why they decided to study science subjects, when teachers allow positive relationship with students and stress student participation and classroom activities. 
Another research by Kieran (2007) in his findings on factors influencing students' choice of experimental science subjects suggest that interest, enjoyment, university course and career requirements have most influence on students' choices. More recently Tesfaye (2010) found out that the declining interest of students in choosing physics subject as well as lack of enthusiasm to take physics courses as a college major is an international problem. Of the several attempts made to boost students' interest in physics, some that have proved very fruitful according to Tesfaye (2010), include introducing an innovative physics curricula, use of students' centered methods and introducing interesting ways of teaching sciences from early years. Many students who find studying sciences due to parental, teacher, gender influence or personal interest gradually began to like sciences because of good teaching methods, facilities and encouragements. Others in spite of adequate conditions still have poor perceptions and are likely to change courses later.

Gender and its effect on career choice has long been a research interest. However according to Wai and Watt (2009) most high status, high salary occupations are skewed to higher male participation and academic studies on gender-typed career choice are concentrated on females' lower participation in careers in science, technology, engineering, and math (STEM). Gerhard (2009) discovered in his study on children becoming scientists and the effect of gender on parental education, that female scientists were more likely than men to mention parental influences and that father were more likely than mothers to be career influencers. He also discovered an interaction was found between the scientist gender and parental education when predicting a parent nomination as influencer. One way parents can influence choice is by sending them to good schools and ensuring they get proper counseling about career choices. The kind of environment they find themselves also matters when it comes to choosing a career (Ohiwerei \& Nwosu, 2009). Wai and Watt (2009) also reviewed that in male-dominated careers like STEM, women, as a gender minority in the workplace, encounter barriers such as insufficient organizational support that attends to their needs, sexual harassment, stereotyping comments from colleagues, and difficulties engaging with male colleagues in social activities and conversations. This is enough reason for some females not to choose careers in sciences and so avoid science subjects.

Parents and teachers affect science subject choices of students but as much as interest was more a factor for female they discovered pay was a factor for males. But interestingly a strong background in science and mathematics also influence choices. This is where teachers can help. They are responsible for transmitting theory to practice and they are the ones teaching, so they really need to work hard to help the students have a strong background through good teaching methods, good classroom learning environment and good teacher-pupil relationship. Personally as a kid, I had a strong liking for science but at senior secondary school I had to battle with my physics classes because at that time I had a boring physics teacher who I can say did not really understand what the topics were and so found it difficult to communicate to us. Though I scared through as a science student but it took extra effort and personal interest to overcome the discouragement from my physics teacher. Thinking back I could imagine combining a good physics teacher with my personal interest to learn physics it could have resulted to a lesser struggle and better performance. But for personal interest I could have opted out of science completely. Parental factor had no effect in my case to study sciences. But this is not the case for all. Different researchers have different findings and perceptions hence more researches in this area are been carried out.

Omosewo (2003) on parental influences also discovered that the choice of physics of female students was mostly influenced by parents. Their result showed that parental influence was $48 \%$, school counselors $31 \%$, peer pressure $9 \%$, friends and relatives $10 \%$ and self $-1 \%$. Thus more enlightenment should be given to parents to encourage their females more in choosing science subjects. Osipow and Fitzgerald (1996) stated, "Gender is clearly one of the most powerful of all influences on vocational behavior". A teacher's method can determine whether a student can have positive interest in the subject or not. According to Ohiwerei and Nwosu (2009), a student may like or try to like a subject but if the teacher is a little eccentric, he tends to trail off the subject matter and make it hard for students to keep up with him, also a soft talker who is a teacher may force the students to stop noise during classes if they must hear him. Therefore lack of proper teaching method can lead to failure. The choice of science subject may depend on the teacher's generosity and attitude to students. 
An important factor that influences a student choice of science subject is profession which is a driving force on student interest and can foster positive perception of science (Ovri, 1999). Many youths make up their minds on their future profession before stepping into secondary school. This goes a long way to determine the attitude of students towards the science subjects. For instance hardly can a student who has made up his mind a read engineering be made to develop positive interest in literature talk of selecting it as a subject for senior secondary classes. When such students are asked about their perceptions of science the answers are always positive. Correll (2001) reviewed that the career process occurs throughout as individuals make decisions on occupation. She also reviewed that the ratio of females to males decline as young people move towards quantitative professions, physical sciences and engineering in contrast with the vast movement to other professions such as law and medicine and like others have researched, teaching professions.

As this project studies the factors which affect students choice of science subjects as they affect students perception of sciences' in Nigeria, a number of factors have been mentioned but the researcher considered the parental factors, teacher factors, personal factors and gender factors.

\section{Statement of the problem}

Many students are offering sciences but have poor perceptions of science subjects as a result of the factor that influenced their choice, whether parental, teacher or gender factors. Recently the researcher had a personal interview with three persons without job satisfaction due to wrong perception resulting from influences at the time of subject and career choice. One of them having obtained a degree in science could get a job in a government establishment, but has no job satisfaction. Because he has discovered he has interest in another field. Since he cannot get the job with his qualification went back to do a BSC program at the university in his choice area before proceeding from there.

There are several others misguided by parents, teachers and gender-factors that are regretting and wishing to start all over again. Many science teachers today are happy but did not do education courses at the university because of the low prestige attach to it but they are now made to pay heavily to do a post graduate study in education to retain their jobs. The problem of wrong choice resulting to wrong perception may cause the students so much pain later in live. Several researchers have stated their findings of the most critical reasons for students' choice of science subjects (Ugboduma, 2009; Duyilemi \& Olusa, 2008), but the fact remains that the result varies from research to research and from place to place.

The purpose of this research is to further validate the result of previous researches on factors affecting career choice and perceptions of students towards their study of science. Specifically it found out which of parental, teacher or personal interest factors affected students the most in their choice of science subjects and to find out the perceptions they have about science subjects. It also found out if boys and girls have similar perceptions of science learning.

\subsection{Research question}

One research question was stated for the purpose of this research. Which of the parental, teacher, personal interest or gender factors has influence on more of the students in their choice of science subject?

\subsection{Research hypotheses}

Four research hypotheses were stated for this research:

$>$ There is no significant difference between students influenced by personal interest and those influenced by parents in their perceptions of science subjects.

$>$ There is no significant difference between students influenced by personal interest and those influenced by teachers in their perceptions of sciences. 
$>$ There is no significant difference between students influenced by teachers and those influenced by parents in their perceptions of science subjects.

$>$ There is no significant difference between boys and girls perceptions of science subjects.

\section{Method}

In this study a descriptive survey design was adopted. And a total of 180 senior secondary III students preparing for their May/June SSCE exams were used for the study. The sample consists of a total of 91 boys and 89 girls selected from four secondary schools in Delta state, Nigeria that met with the researcher's criteria. Two of the schools were single sex schools while the other two were mixed schools. This is because they have already chosen the subjects for their forth coming exams. 45 students were selected from each of the classes through simple ballot methods.

A research questionnaire designed to elicit appropriate and unbiased responses through careful administration was used. It was tagged subject choice and perception questionnaire (SCAPQ). The questions in the questionnaire are based on the research question and the four hypotheses formulated for this study. It has 2 sections and is made up of 20 items to allow for easy analysis. Section A is on student's data and subjects chosen while section B is on the factors that affect students' choice of subjects and their perceptions of sciences. Section B consists of a Yes or No responses that attracts 2marks for Yes and 1mark for No. Question 6 was used to generate data for answering research question one. Split-half reliability co-efficient of 0.73 was obtained for the questionnaire which makes the instrument reliable for use. All the 180 questionnaires administered were returned and used for the data analysis.

\section{Results}

The results of analysis of the data gotten from the questionnaire are stated below and used to answer the research question and to test the hypotheses.

Research question one: Which of the parental, teacher, gender or personal interest factors, has the highest influence on students in their choice of science subject?

\section{Table 1}

Influence factor

\begin{tabular}{ccccc}
\hline parental & teacher & gender & personal interest & total \\
\hline $59(32.7 \%)$ & $37(20.6 \%)$ & $11(6.1 \%)$ & $73(40.6 \%)$ & 180 \\
$\mathrm{X}=16.03$ & 14.59 & 14.72 & 17.06 & \\
\hline
\end{tabular}

From the table above it is seen that more of the students were influenced as a result of their personal interest. $40.6 \%$ had personal interest in science careers and science subject. This was followed by $32.7 \%$ of the students, who were influenced by their parents, $20.6 \%$ of the students were influenced by their science teachers while only $6.1 \%$ were influenced by gender.

\subsection{Test of hypothesis one}

There is no significant difference between students influenced by personal interest and those influenced by parents in their perceptions of science subjects. From the results it is seen that at 0.05 level of significant $t$-cri value is 1.96 , which is less than the calculated value of 2.16 , thus the hypothesis 1 is rejected meaning there is a significant difference in the perceptions of science students influenced by personal interest and those influenced by their parents, with those influenced by personal interest having better perceptions of sciences. 
Ezeweani, U. L. \& Atomatofa, R. O.

Table 2

Showing choice scores of those influenced by personal interest and parents

\begin{tabular}{cccccccc}
\hline Influence factors & $n$ & $\mathrm{X}($ mean $)$ & $S D$ & $d f$ & t-cal & t-cri & remark \\
\hline personal interest & $73(40.6 \%)$ & 17.56 & 4.07 & 130 & 2.16 & 1.96 & significant \\
parents & $59(32.7 \%)$ & 16.03 & 4.04 & & & & \\
\hline
\end{tabular}

\subsection{Test of hypothesis two}

There is no significant difference between students influenced by personal interest and those influenced by teachers in their perceptions of science subjects:

Table 3

Personal influence and teacher influence factors

\begin{tabular}{cccccccc}
\hline Influence factors & $n$ & $\mathrm{X}($ mean $)$ & $S D$ & $d f$ & t-cal & t-cri & remark \\
\hline personal interest & $73(40.6 \%)$ & 17.56 & 4.07 & 108 & 4.00 & 1.96 & significant \\
teachers & $37(32.7 \%)$ & 14.59 & 3.46 & & & & \\
\hline
\end{tabular}

Table 3 shows that the $\mathrm{t}$-cal at 4.00 is greater than the t-cri value at 1.96 . This leads to rejection of Hypothesis two. Therefore there is a significant difference in the perceptions of students influenced by their personal interest and those influenced by their teachers.

\subsection{Test of hypothesis three}

There is no significant difference between students influenced by teachers and those influenced by parents in their perceptions of science subjects.

\section{Table 4}

Choice scores of those influenced by teachers and parents

\begin{tabular}{cccccccc}
\hline Influence factors & $n$ & $\mathrm{X}($ mean $)$ & $S D$ & $d f$ & t-cal & t-cri & remark \\
\hline parents & $59(37.6 \%)$ & 16.03 & 4.04 & 118 & 1.86 & 1.96 & NS \\
teachers & $37(32.7 \%)$ & 14.59 & 3.46 & & & & \\
\hline
\end{tabular}

The calculated value (1.86) is lesser than the t-cri value at 0.05 level of significance (1.96) making the hypothesis three accepted. Therefore there is no significant difference in the perceptions of students influenced by parents and those influenced by teachers towards the science subjects.

\subsection{Test of hypothesis four}

Table 5

Gender differences

\begin{tabular}{cccccccc}
\hline gender & $n$ & $\mathrm{X}($ mean $)$ & $S D$ & $d f$ & t-cal & t-cri & remark \\
\hline boys (male) & 91 & 16.22 & 4.13 & 78 & 0.63 & 0.96 & significant \\
girls (female) & 89 & 16.45 & 3.96 & & & & \\
\hline
\end{tabular}

From the result in table 5 above, it is seen that the $\mathrm{t}$-cal is 0.63 which is lower than the $\mathrm{t}$-cri at 1.96. Therefore the hypothesis 4 is accepted meaning there is no significant difference between the perceptions of 
boys and girls in their choice of science subjects.

\section{Discussions}

The results revealed that the students whose choice of science subjects/careers were as a result of personal interest had better perceptions of science than those whose choices were as a result of their parents or teachers influence. This is in line with other research findings and views of other researchers (Kieran 2007, Oriahi, Uhumuavbi, \& Aguele 2010). The result also revealed no significant difference between perceptions of students influenced by parents and those influenced by teachers. This shows that students influenced by either parents or teachers have similar views of science. However their views were not as strong as those influenced by their personal interest. Therefore students should be left to decide for themselves if they are really interested in studying sciences. They can be encouraged by parents and teachers to gradually increase their interest in sciences but should not be compelled as this may be a reason for them having a negative perception of science. On gender there was no significant difference between perceptions of boys and girls. This result contrast that of Oriahi, Uhumuavbi, and Aguele (2010) that found out that boys had better views of science than girls but the result agrees with Ovri (2000) that there was no significant difference between perceptions and subject choices of boys and girls.

\section{Conclusion and recommendations}

In conclusion students can be encouraged to study science subjects by teachers and parents but care must be taken not to force them because this can make them study the subjects but lose interest thereby resulting to poor perceptions or views of science subjects and careers. Since those who have personal interest had better perceptions of sciences they should be encouraged and not discouraged by teachers, method of teaching, relationship with teachers or gender.

\section{References:}

Adedibu, A. A. (1986). Unemployment issues trends and implication for vocational guidance. Educational and Vocational Guidance Journal, 1, 54-55.

Akpan, E. U. (1986). Factors affecting students choice of science subjects in Nigerian secondary school. Research in Science and Technological Education, 4, 99-109. $<$ http://dx.doi.org/10.1080/0263514860040110>

Corell, S. T. (2001). Gender and the career choice process: The role of biased self-assessments. American Journal of Sociology, 106(6), 1691-1730. <http://dx.doi.org/10.1086/321299>

Durojaiye, M. O. A. (1973). Educational and occupational prestige in Nigerian secondary school pupils. West African Journal of Education, 17(3), 41-49.

Duyilemi, A., \& Olusa, A. (2008). The impact of role modeling and mentoring on the attitude of girls towards science, technology and mathematics education. Proceedings of Science Teachers Association of Nigeria.

Gerhard, S. (2009). Parents who want to influence their children to become scientist. Effect of gender and parental education. Social Studies of Sciences, 39(6), 927-941.

$<$ http://dx.doi.org/10.1177/0306312709335843>

Ginzberg, E. (1957). An approach to general theory. New York: Column university press.

Ipaye, T. (1991). Guidance counseling practice. Ife ife: University press Ile-ife.

Keeves, J. P. (1992). Learning science in the changing world. Cross national studies of science achievement 1970-1984. Australia.

Kieran, J. (2007). Factors influencing students' choice(s) of experimental science subjects within the international baccalaureate diploma program. Journal of Research in International Education, 6(1), 9-39. <http://dx.doi.org/10.1177/1475240907074787>

Ohiwerei, F. O., \& Nwosu, B. O. (2009). Vocational choices among secondary school students. Issues and 
strategies in Nigeria. Asian Journal of Business Management, 1(1), 1-5.

Omosewo, E. O. (2003). Factors influencing female students' choice of physics in selected secondary schools in Ilorin metropolis. Institute Journal of Studies in Education, 1(5), 131-140.

Oriahi, C. I., Uhumuavbi, P. O., \& Aguele, L. I. (2010). Choice of science and technology subjects among secondary school students. Journal of Social Science, 22(3), 191-198

Osipow, S. H., \& Fitzgerald, L. F. (1996). Theories of career development (4th ed.) Boston: Allyn \& Bacon.

Ovri, R. (1999). Factor-based of students choice for subjects and career engagement in Effurun Delta State. Unpublished BSc/Ed project, Delta State University, Abraka.

Tesfaye, S. (2010). Who is joining physics and why? Factors influencing the choice of physics among Ethiopian university students. International Journal of Environmental and Science Education, 5(3), 319-340.

Ugboduma, S. O. (2009). Factors responsible for students' negative attitude towards mathematics and remedies. Mosogar Science Education Journal, 1, 172-176.

Wai, S. K., \& Watt, H. M. G. (2009). Effects of gender and gender role orientation on high school students' teaching perceptions and aspirations in Hong Kong. Monash University, Australia.

Yara, P. O. (2009). Students' attitude towards mathematics and academic achievement in some selected secondary schools in southwestern Nigerian. European Journal of Scientific Research, 36(2), 336-341. 


\section{Appendix}

\section{Subject Choice and Perception Questionnaire (SCAPQ)}

\section{Section A}

Sex:

Class:

Age:

Last position in class:

Future career ambition:

Who influenced you most in your career choice? (parent/ teachers/ gender/ personal interest)

Section B - Perception

(Please tick the correct one: Yes or No questions)

1. There are some science subjects I am not doing now that I will like to do (yes/No

2. I believe science should be taught to all students

3. I will enjoy science more if my teachers are friendly

4. I like my science teachers and methods

5. I will drop science if I fail my science subjects

6. Most Sciences courses are meant for boys

7. I prefer science and hope to continue a career in science

8. I find satisfaction in science.

9. I enjoy all my science classes/subjects

10. I don't like sciences but my parents forced me to study sciences

11. I don't like sciences but my teachers forced me to

12. I like science despite my teachers and teaching methods

13. There are some science subjects am doing that I do not like

14. I hope to change from science to Arts or Social sciences later 
Ezeweani, U. L. \& Atomatofa, R. O. 